\title{
Native and exotic fishes in a Patagonian reservoir with rainbow trout cage culture: spatial and trophic resource use
}

\author{
Diego N. Nabaes Jodar ${ }^{1, *}$, Leandro A. Becker ${ }^{1}$, Pedro Cordero ${ }^{2}$, Guillermo Blasetti ${ }^{2}$ and \\ Víctor E. Cussac ${ }^{1}$ \\ ${ }^{1}$ Instituto Andino Patagónico de Tecnologías Biológicas y Geoambientales (IPATEC), Universidad Nacional del Comahue, \\ CONICET, CRUB, Quintral 1250 San Carlos de Bariloche, 8400 Río Negro, Argentina \\ ${ }^{2}$ Autoridad Interjurisdiccional de las Cuencas de los Ríos Limay Neuquén y Negro (AIC), Cipolletti, Argentina
}

\begin{abstract}
Although the interactions of exotic salmonids with native Patagonian fishes are well known, little is known about the ecology and impact of farmed fish escapees. Salmonid production in Argentina is largely concentrated in the Alicurá reservoir in north Patagonia, where fish community studies have been scarce. Here, we assess and compare the spatial distribution, body size-condition and diet of the different fish species in this reservoir. Strong vertical segregation was observed between exotic rainbow trout Oncorhynchus mykiss (both escapees and wild), dominating the littoral zone, and native Percichthys trucha which dominate the medium and deep strata. Low piscivory-benthivory and high zooplanktivory were observed for rainbow trout, both traits being uncommon at a regional scale. Escaped farmed rainbow trout (ERT) diet included abundant indigestible items along with wild prey. Higher body condition of $P$. trucha close to farms, as well as the regionally unprecedented high incidence of Daphnia sp. in the guts of all the species suggest that farm nutrient discharges have had significant impacts. Finally, the high body condition of ERT, together with their wild food diet and the long dispersal distance observed, demonstrate post-escape success, drawing our attention to potential upstream dispersion affecting the biodiversity and fisheries of Patagonian rivers and lakes.
\end{abstract}

Keywords: aquaculture impact / freshwater salmonid / niche segregation / diet / Patagonia

Résumé - Poissons indigènes et exotiques dans un réservoir de Patagonie avec aquaculture en cage de truites arc-en-ciel : utilisation des ressources spatiales et trophiques. Bien que les interactions des salmonidés exotiques avec les poissons patagoniens indigènes soient bien connues, on connaît peu l'écologie et l'impact des poissons échappés d'élevage. La production de salmonidés en Argentine est largement concentrée dans le réservoir d'Alicurá dans le nord de la Patagonie, où les études sur les communautés de poissons ont été rares. Ici, nous évaluons et comparons la répartition spatiale, la taille du corps et l'alimentation des différentes espèces de poissons dans ce réservoir. Une ségrégation verticale forte a été observée entre la truite arc-en-ciel exotique Oncorhynchus mykiss (à la fois évadée et sauvage), dominant la zone littorale et Percichthys trucha natif qui domine les couches moyennes et profondes. Un faible comportement piscivore-benthivore et un régime zooplanctivore important ont été observés pour la truite arc-en-ciel, les deux traits étant peu fréquents à l'échelle régionale. Le régime de la truite arc-en-ciel échappée des cages (ERT) comprenait des composés indigestes abondants et des proies sauvages. Un coefficient de condition élevé de $P$. trucha près des fermes, ainsi que l'incidence locale sans précédent de Daphnia sp. dans les estomacs de toutes les espèces suggère que les rejets de nutriments aquacoles ont eu des impacts importants. Enfin, le bon état corporel des ERT, ainsi que leur régime alimentaire et la longue distance de dispersion observée, démontrent une réussite après l'échappée, attirant notre attention sur la dispersion potentielle en amont affectant la biodiversité et la pêche des rivières et des lacs patagoniens.

Mots-clés : impact aquacole / salmonidé d'eau douce / ségrégation de niche / alimentation / Patagonie

\footnotetext{
${ }^{*}$ Corresponding author: diegonabaes@gmail .com
} 


\section{Introduction}

Accidental release of cultured fish and nutrient inputs through organic waste are two of the main impacts of salmonid cage-culture on ecosystems worldwide (Naylor et al., 2005; Podemski and Blanchfield, 2006). Salmonid escapees from culture operations may alter native species composition, abundance and distribution of organisms from the lowest to the highest trophic levels, and ultimately, ecosystem services(Findlay et al., 2009; Johnston et al., 2010; Olaussen and Liu, 2011).

Salmonid escapees are expected to have long-term environmental effects on the receiving communities, given their high dispersion capacity and longevity, in addition to the high frequency and massive nature of escape events (Podemski and Blanchfield, 2006; Arismendi et al., 2009; Bourret et al., 2011; Patterson and Blanchfield, 2013). Ecological impacts include predation, competition and species replacement (Habit et al., 2010; Johnston and Wilson, 2014). A variable degree of escaped fish fidelity to farms has been reported, but dispersal does occur eventually, as does the major use of surface layers (Bridger et al., 2001; Skilbrei, 2010, 2012; Chittenden et al., 2011; Patterson and Blanchfield, 2013).

Salmonid escapees are able to consume wild food, having diets similar to wild fishes (i.e. native species, or previously introduced exotic free-living species; Soto et al., 2001; Naylor et al., 2005; Johnston and Wilson, 2014). However, cases have been reported where escapees feed heavily on farmed pellets (Abrantes et al., 2011), or consume only indigestible items floating on the surface (Rikardsen and Sandring, 2006; Skilbrei, 2012). Feeding behavior seems to be time-dependent on the escape, and age at escape (Rikardsen and Sandring, 2006), but might also depend on interactions with wild fishes (Skilbrei, 2012). Interaction between escaped and wild fishes is likely to be context-dependent (Podemski and Blanchfield, 2006), with more intense effects (e.g. displacement by competition) expected in systems inhabited by species that may share resources with the escapees (Naylor et al., 2005; Johnston et al., 2010; Johnston and Wilson, 2014). Also, when wild populations of conspecifics exist, genetic introgression of farm-adapted genes could reduce fitness through loss of local adaptations (McGinnity et al., 2003; Skaala et al., 2006; Hindar and Fleming, 2007; Bourret et al., 2011).

Given that the productivity of most freshwater systems is regulated by phosphorus (Sterner and Schulz, 1998), and that this nutrient is massively discharged from aquaculture cages, pollution is expected (Bureau and Hua, 2010). Changes in organic matter and nutrient concentrations as well as plankton abundance and composition have been reported in lakes and reservoirs following fish culture (Guo and Li, 2003; Reid et al., 2006; Bristow et al., 2008; dos Santos et al., 2009; Paterson et al., 2010).

Cage culture not only implies an input of nutrients, organic matter and fish to the environment, but also an input of structure (Johnston et al., 2010). Thus, the distribution of organisms might be altered by the presence of farms, which generally attract fish, favoring their growth and condition (Podemski and Blanchfield, 2006; Johnston et al., 2010).

In Argentina, freshwater cage culture of the exotic rainbow trout Oncorhynchus mykiss (Walbaum) has been developed mainly in Alicurá reservoir (Fig. 1), whose main tributaries derive from two headwater lakes located inside National Parks.

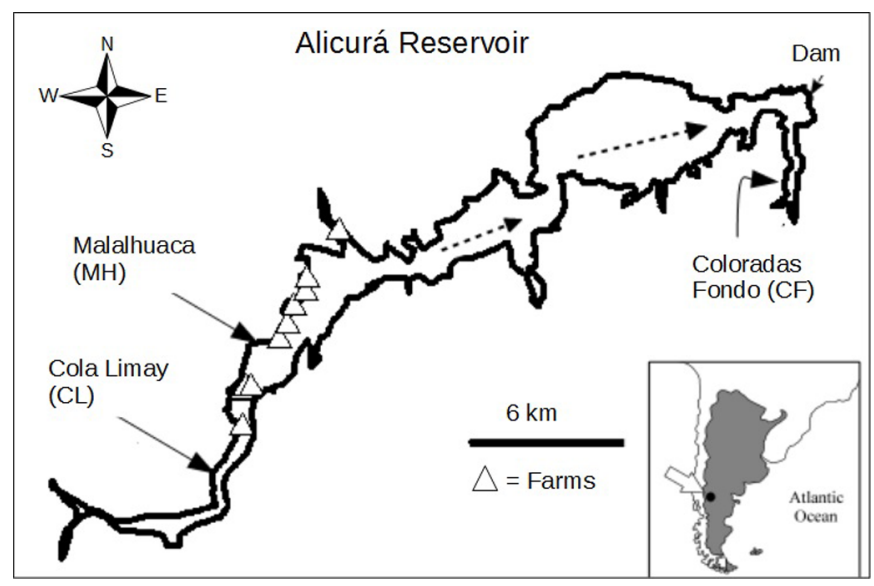

Fig. 1. Sampling sites in Alicurá reservoir, and its location on a reference map of the region (inset). White triangles represent the location of cage-culture facilities for rainbow trout production. Dotted arrows show the direction of water flow. Black bar is a distance reference of $6 \mathrm{~km}$.

Farming activities in the reservoir began in 1992, reaching 1800 ton year $^{-1}$ in 2009 (Zeller et al., 2009).

Farm escapees in Alicurá reservoir are highly abundant and coexist with a fish community which has already been altered due to an impounded river and several invasive salmonid species introduced for recreational fishery purposes (Pascual et al., 2007; Cussac et al., 2014). Rainbow trout, along with other salmonid species, represent an important economic resource for recreational/sport fishery (Vigliano et al., 2007). In this way, two economically oriented views (i.e. fish farming and fishing tourism) coexist and interact with each other, and with views from academia and government institutions of conservation of the native aquatic species (Pascual et al., 2009).

Previous studies in the shallow littoral of Alicurá reservoir detected a decreased abundance of the native Patagonian silverside Odontesthes hatcheri (Eigenmann) and Percichthys trucha, in contrast to an increased abundance of escaped farmed rainbow trout (ERT). This pattern was pronounced close to the farms (Temporetti et al., 2001), with highly fluctuating abundance between years, probably reflecting massive escape events (Cussac et al., 2014).

Previous reports on trophic relationships studied only the shallow littoral of the reservoir (Cussac et al., 1998; Macchi et al., 1999), and ERT were not discriminated from wild rainbow trout (WRT). Studies of the ecology of ERT are also lacking from other farmed lakes and reservoirs of Argentina. In this work we use both community (species relative abundance) and individual (stomach content, size and condition) approaches to explore the ecology of farm escapees and the effects of salmonid cage culture on the recipient community of Alicurá reservoir, 25 years after the initiation of rainbow trout aquaculture.

\section{Materials and methods}

Alicurá reservoir is a large, man-made hydropower reservoir (area: $67.5 \mathrm{~km}^{2}$, mean depth: $48 \mathrm{~m}$ ) located on the Limay River in southwestern Argentina (Fig. 1). Inaugurated 
in 1985 , it is located $87 \mathrm{~km}$ downstream of lake Nahuel Huapi, in the transition zone between Andean forest and steppe.

Along with ERT, the native puyen Galaxias maculatus (Jenyns), big puyen Galaxias platei Steindachner, the catfishes Hatcheria macraei (Girard) and Diplomystes viedmensis MacDonagh (Muñoz-Ramírez et al., 2014), O. hatcheri, P. trucha (including, according to Ruzzante et al., 2006, 2011; several nominal forms considered by López-Albarello, 2004), and the exotic rainbow trout, Atlantic salmon Salmo salar Linnaeus, brown trout Salmo trutta Linnaeus, and brook trout Salvelinus fontinalis (Mitchill), have been reported in the reservoir (Cussac et al., 1998; Macchi et al., 1999; Aigo et al., 2008). O. hatcheri, P. trucha, rainbow trout, and S. trutta are the most frequently captured species.

Fish were caught with two sets of gillnets, working overnight between February 14 and April 14, from year 2012 to 2014, as part of a major survey conducted by Autoridad Interjurisdiccional de las Cuencas de los Ríos Limay Neuquén $y$ Negro (AIC). Nets were set at a maximum of three locations, and in three to five depth strata, depending on year and month (see Appendix 1 for details). The sites were: (1) Malalhuaca $(\mathrm{MH})$, located in the trout farm area, at c. $900 \mathrm{~m}$ from the nearest one; (2) Cola Limay (CL), $1500 \mathrm{~m}$ upstream of (southward) the southernmost farm; and (3) Coloradas Fondo (CF), $22 \mathrm{~km}$ downstream from (northward) the northernmost farm (Fig. 1). All gillnet sets consisted in up to seven bar mesh sizes, from 15 to $70 \mathrm{~mm}$, each 10 or $25 \mathrm{~m}$ in length; sampling therefore was limited to large juveniles and adults, excluding G. maculatus and H. macraei (Aigo et al., 2008). Information on water level of the reservoir on the sampling dates was provided by AIC (Fig. 2).

Number of individuals, species, weight $(W)$, and length $(L$; fork for salmonids and total length for natives) were registered, and the stomachs dissected for diet analysis (in March 2012, only rainbow trout stomachs could be obtained). Wild and farmed rainbow trout were identified according to their external characteristics (Temporetti et al., 2001; Fiske et al., 2005). However, since previous studies in Chilean Patagonia have found that ERT and WRT can exhibit no obvious phenotypic differences (Consuegra et al., 2011), estimated abundances of ERT in the present study are probably underestimated (conversely, diet overlap between ERT and WRT may be overestimated). Stomachs were extracted in the laboratory and individually preserved in alcohol at $-20^{\circ} \mathrm{C}$ until content analysis under a stereoscopic microscope. Some prey items were grouped based on their taxonomic linkage or spatial habits: (1) terrestrial insects, (2) aquatic immature insects, (3) Chilina sp. (Gastropoda), (4) Decapoda (i.e. Samastacus spinifrons and Aegla sp.), (5) Daphnia sp. (Cladocera), (6) G. maculatus, (7) Big fish (P. trucha and unidentifiable fish), (8) rodents, (9) vegetable debris, (10) synthetic fragments, (11) pumice stones. For each stomach we measured the volume of each previously defined group by water displacement, after thoroughly reducing the amount of excess liquid (Hyslop, 1980), and the number of empty stomachs was recorded by species. Volume was selected because of the wide size range of prey categories (Hyslop, 1980; Wallace, 1981). The measure of diet selected for analysis was the percentage that each food category contributed to the total volume of food in each stomach (Wallace, 1981), allowing us to represent equally the different predator sizes within each species (Ahlbeck et al., 2012).

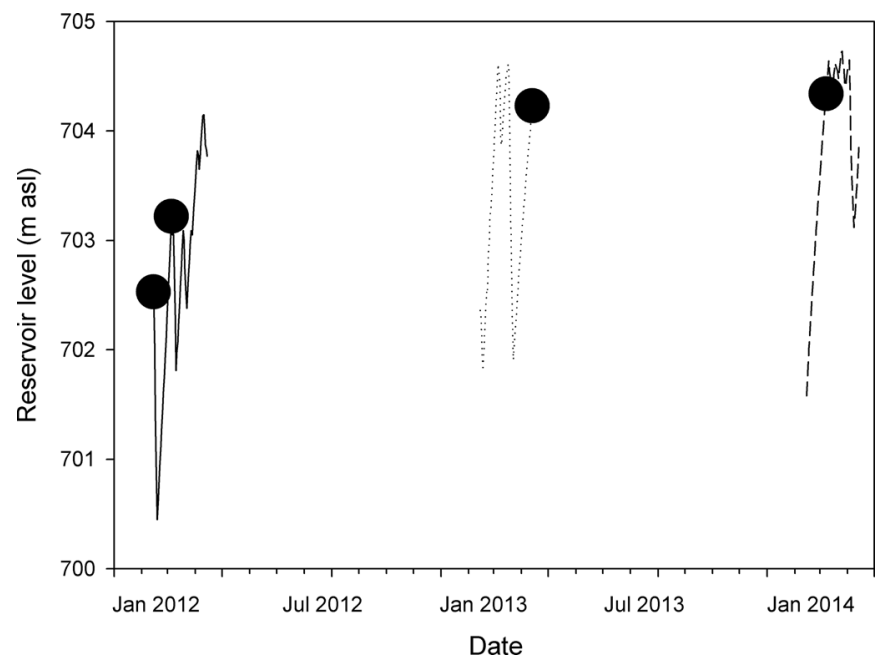

Fig. 2. Water level in meters above sea level for Alicurá reservoir on sampling dates (black circles between February 14 and April 14, from year 2012 to 2014).

Since the net mesh sizes and lengths used were not the same for all sampling, individual captures were analyzed in relation to the total capture of each net, in terms of relative abundance, and null captures were not considered. Generalized linear models (GLMs) with Binomial distribution and logit link function (Warton and Hui, 2011) were developed to assess the relationship between the probability of capture of each species, with three predictors, and all possible interactions (one model for each species), using R 3.2.3 (R Core Team, 2015). The dependent variable was formulated as the ratio between the number of individuals of species " $i$ " in net " $j$ " and the number of all individuals in net " $j$ ". The $g l m$ function in R (R Core Team, 2015) then uses the total number of captures in that specific net for weighting each ratio. The predictor variables were depth (continuous), site, and year (treated as factors, with three levels each). After exploratory data analysis of predictor and dependent variable relationships, depth was transformed with base 2 logarithm in order to linearize the relation between variables and improve fit. Absence of significant correlation between predictors was checked for each model using the variance inflation function (vif) on the R package "car" (Fox and Weisberg, 2011). When overdispersion was detected, standard errors were corrected using quasi-GLM models, with variance corresponding to $[\phi * u](u=$ mean, $\phi=$ dispersion parameter; Zuur et al., 2009). After removing missing values, the significance of predictors was assessed by analysis of deviance (chi-squared tests, except for quasi-models where $F$ tests were used), with sequential dropping of the least significant effect $(p<0.05)$. Multiple pairwise comparisons were performed by applying Tukey contrasts using the $\mathrm{R}$ package "multcomp" (Hothorn et al., 2008). Plots were built with the R packages "ggplot2" (Wickham, 2009) and "effects" (Fox, 2003).

Body length and condition of each species were evaluated for associations with depth, site and year of capture. For body length data, GLMs with gamma distribution and inverse link were used, except for P. trucha, for which large differences in variance per site had to be modeled using generalized least squares with different standard deviations per site. Condition 
Table 1. Binomial generalized linear models (GLMs) results for the relative abundance per species. Predictors with statistically significant effects assessed by backward model selection are listed for each model ( $* p$-value $<0.05 ; * * p$-value $<0.01 ; * * * p$-value $<0.001)$, as well as the models percent explained deviance.

\begin{tabular}{llc}
\hline Species & Predictor variables & Explained deviance (\%) \\
\hline Escaped rainbow trout & Depth $* * *$, site:year $*$ & 85.4 \\
Wild rainbow trout & Depth $* * *$, site $* * *$, year** & 87.6 \\
Brown trout & None & - \\
Percichthys trucha & Depth:year* & 85.1 \\
\hline
\end{tabular}

was assessed with the Scaled Mass Index (SMI), and compared across predictors using GLMs with Gaussian distribution (Peig and Green, 2009; Maceda-Veiga et al., 2014). The SMI is a method for standardizing body mass for a fixed length, based on the scaling relationship between mass and length, taking into account the error of both variables, and is calculated with the following formula:

$$
\text { Scaled mass index }(\mathrm{SMI})=W_{i} \cdot\left[L_{0} / L_{i}\right]^{b_{S M A}}
$$

where $W_{i}$ and $L_{i}$ are the weight and length of each specimen, respectively, $L_{0}$ is the mean length of each species sample, and $b_{S M A}$ is the scaling exponent, that is, the slope of a standardized major axis regression of the mass-length relationship (Peig and Green, 2009; Maceda-Veiga et al., 2014). The significance $(p<0.05)$ of predictors was assessed by $F$-tests, and pairwise comparisons made using Tukey contrasts (R package "multcomp").

Particular model assumptions were checked by graphical analysis via plots of fitted and predictor values vs. residuals, and normal probability plots (Zuur et al., 2009; Warton and Hui, 2011).

Trophic niche breadth was assessed with the standardized Levins' measure (Levins, 1968), as it gives more weight to dominant prey groups than the Shannon-Wiener Index of diversity, and is more appropriate for comparisons across species (Marshall and Elliott, 1997). Values of Levins' measure closer to zero represent high diet specialization in one or few items, while values close to one reflect broad niche and diverse diet. The Schoener index (SI; Wallace, 1981) was used to assess diet overlap between species, separately, at the two main depth strata identified with the fish distribution analysis (i.e. $<4 \mathrm{~m}$ and $10-50 \mathrm{~m}$ ). This index ranges from 0 (no overlap) to 1 (complete overlap), and overlap is considered significant if $\mathrm{SI} \geq 0.6$ (Wallace, 1981). The food categories that characterize each fish species were identified using stepwise Discriminant Analysis (DA) with angular transformed average of volume percentages, thus obtaining significant Discriminant Functions (DF) and the main food categories for each DF. Values of significant DFs were compared between species with one-way ANOVAs, at $<4 \mathrm{~m}$ and at $10-50 \mathrm{~m}$ separately. Diet analyses and plots were conducted with Statistical Package for Social Sciences (SPSS ${ }^{\circledR}$; Norusis 1986) and Sigmastat .

Differences in proportions of empty stomachs between ERT, WRT, $S$. trutta and $P$. trucha were evaluated with a binomial GLM using the proportion of empty stomachs by species in each net capture as response variable, and species as a predictor, using R 3.2.3 (R Core Team, 2015). The other species lack sufficient empty stomach data for the analysis.
Depth, site, and year of capture could not be evaluated as predictors of stomach emptiness because of poor representation of the different species across these variables.

\section{Results}

Individuals of three native and three exotic (salmonid) species were captured, including WRT and ERT, with lengths between 10.2 and $67.9 \mathrm{~cm}$ (see Appendix 2 for captures data). The number of null captures was 4 out of 31 net settings, rendering $N=27$ for all relative abundance analysis.

\subsection{Relative abundance}

Significant effects on the relative abundance of ERT were found for depth (overall explained deviance $=85.4 \% ; F=67.8$; $\left.p<10^{-6}\right)$, and for the interaction between site and year $(F=4.18 ; p<0.022$; Tab. 1). For every meter in depth, the estimated mean decrease in ERT capture odds was $17.7 \%$ (Fig. $3 \mathrm{~A}$ ). Tukey contrasts revealed that only one pair of site-year combinations differ significantly, i.e. 2013-MH vs. 2012-MH $(z=3.03 ; p<0.036)$, with estimated odds of capturing ERT 3.8 times higher in 2013-MH.

The model for WRT was the only one without overdispersion, and included significant effects of depth $\left(X^{2}=57.5\right.$; $\left.p<10^{-13}\right)$, site $\left(X^{2}=22.7 ; p<10^{-4}\right)$, and year $\left(X^{2}=11.9\right.$; $p<0.0027$ ), but no interactions between them (overall explained deviance $=87.6 \%$; Tab. 1). The effect of depth on the probability of capture of WRT was negative, with odds decreasing $19 \%$ with every meter in depth (Fig. 3A). Tukey contrasts revealed that in year 2012 the odds for WRT were 2.24 times lower than in year $2013(z=3.12 ; p<0.0048)$. At site MH the odds of capturing WRT were $63.1 \%$ lower than at CL $(z=-3.253 ; p<0.004)$. Finally, site CL showed odds for WRT 9.98 times greater than those at CF $(z=3.7 ; p<0.0007)$.

In the case of $S$. trutta, none of the predictors evaluated in the binomial GLM (with corrected overdispersion) had a significant effect ( $p>0.05$; Tab. 1).

Distribution of $P$. trucha was explained by the interaction between depth and year of capture (overall explained deviance $=85.1 \% ; F=5.02 ; p<0.017 ;$ Tab. 1$)$. The probability of capture for $P$. trucha was associated positively with depth, but with a lower abundance at shallow depth in 2013 than in 2012, and similar values for both years at greater depths (Fig. 3B). Year 2014 showed no statistical differences from $2013(z=-0.11 ; p>0.91)$ or $2012(t=1.38 ; p>0.18$; Fig. 3B); however, as in 2013 , P. trucha was only captured below $2 \mathrm{~m}$ depth. 
(A)

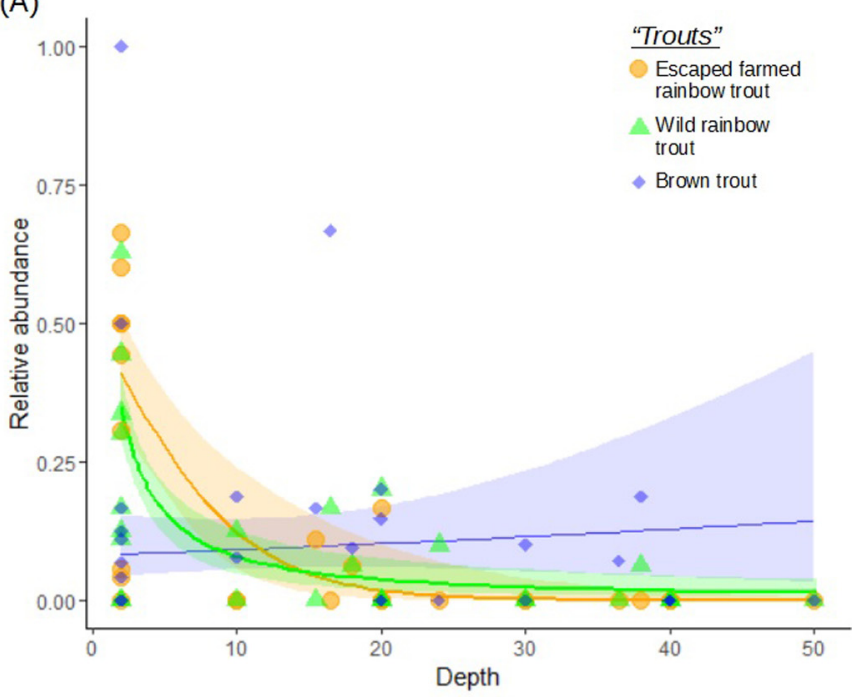

(B)

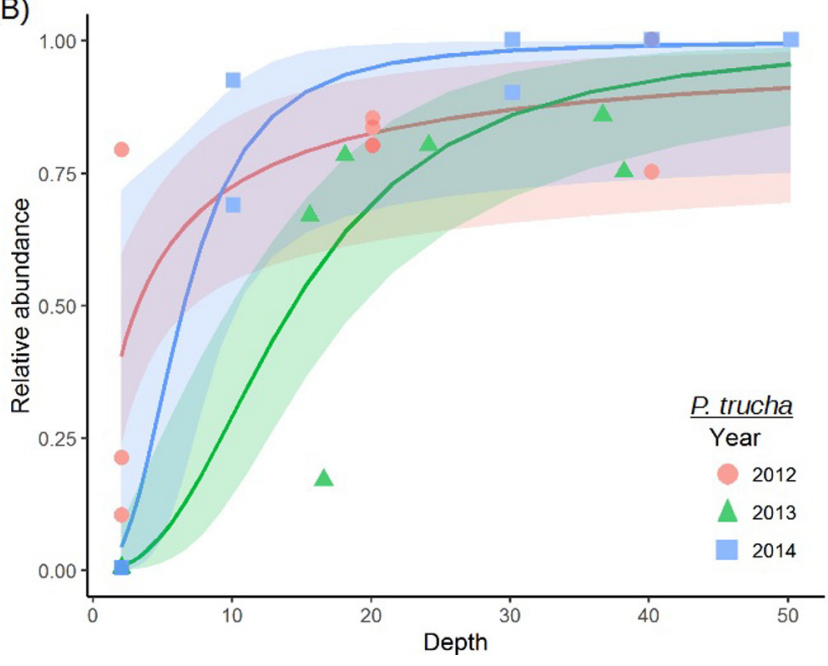

Fig. 3. GLM estimates of (A) relative abundance $v$ s. depth (m) for trout (separate model for each group), and (B) relative abundance vs. depth $(\mathrm{m})$ by year of capture for Percichthys trucha. Ribbons along lines represent $95 \%$ confidence intervals, and points are capture data.

\subsection{Body length}

Variation in body length of ERT was explained by the interaction between site and year of capture $(N=98$; explained deviance $=28.2 \% ; F=4.82 ; p<0.01)$, with length at site $\mathrm{CL}$ in year 2012 averaging between 10 and $15 \mathrm{~mm}$ less than at every other site-year combination (Tukey tests, $p<0.05$; Fig. 4A).

WRT showed a similar body length pattern to that of ERT, with a significant interaction between year and site of capture $(N=86$; explained deviance $=40.2 \% ; F=12.2 ; p<0.0009)$, with smaller fish at site CL in year 2012, but also fish at MH in year 2012 significantly smaller than some site-year combinations (Tukey tests, $p<0.05$; Fig. 4A).

$S$. trutta length was not associated with any of the predictor variables $(N=40$; GLM; $p>0.05)$.

Body length of $P$. trucha was explained by year of capture $\left(N=184 ; X^{2}=5.97 ; p<0.05\right)$ and by the interaction between site and depth $\left(X^{2}=9.2 ; p<0.001\right)$. P. trucha were $36 \mathrm{~mm}$ larger on average in 2012 than in $2013(z=-2.394 ; p<0.045$; Fig. 4A), and also larger at sites CL $(z=3.96 ; p<0.0003)$ and MH $(z=3.4 ; p<0.003)$ than at $\mathrm{CF}$, but only for shallow and medium depths (2-20 m; Fig. 4C).

\subsection{Condition}

The SMI of condition for ERT and $S$. trutta, was not associated with any of the predictor variables (GLM, $p>0.05$ ).

WRT SMI variation was explained by the interaction between site and year of capture (explained deviance $=24.5 \%$; $F=4.7 ; p<0.035$ ), with smaller SMI at MH in year 2012 than at CL-2012, CL-2013 and MH-2013 (Tukey tests, $p<0.05$; Fig. 4B).

In the case of $P$. trucha, SMI was negatively associated with depth $(F=5.9 ; p<0.017)$, decreasing $0.5 \mathrm{~g}$ in average length for every meter in depth, and it was also explained by the interaction between site and year of capture $(F=5.36$; $p<0.0016$; overall explained deviance $=33 \%$ ). Fish at $\mathrm{MH}-$ 2013 and at CL-2013 showed the greatest SMI values (Fig. 4B).

Finally, differences were found in SMI between ERT and WRT, with a mean value $49.3 \mathrm{~g}$ higher for the former ( $t$ test, $t=5.477$; $p<0.001$; Fig. 4C).

Three more species were captured in very small numbers; S. salar $(N=3), G$. platei $(N=1)$, and O. hatcheri $(N=12)$. The latter was captured exclusively at $<4 \mathrm{~m}$ depth at $\mathrm{CF}$ in year 2013. In consequence, these species were not evaluated in terms of distribution, size and condition.

\subsection{Diet}

WRT consumed a high percentage of Daphnia $s p$. $($ mean $=$ $44 \%$ ) and terrestrial insects (28\%), and small quantities of several other items ( $<8 \%$ each), while ERT consumed fewer Daphnia sp. (34\%) and terrestrial insects $(20 \%)$, but more indigestible items, i.e. plant and synthetic fragments (23\%), and pumice stones $(10 \%)$. S. trutta preyed heavily on small puyen $(30 \%)$, but also consumed a high proportion of pumice stones (18\%), and large items like rodents (10\%) and big fishes (12\%). The two $S$. salar stomachs analyzed contained small puyen (50\%), snails (28\%) and Daphnia sp. (22\%). Among the natives, P. trucha preyed mainly on aquatic insects (38\%), Daphnia $s p$. $(26 \%)$, small puyen $(20 \%)$, and decapods $(8 \%)$. Finally, $O$. hatcheri had a narrow diet, comprised mainly of snails $(55 \%)$ and Daphnia sp. (29\%), followed by terrestrial (9\%) and aquatic (5\%) insects (Fig. 5).

The SI (Tab. 2) showed the highest diet overlap between ERT and WRT at $<4 \mathrm{~m}$ depth $(\mathrm{SI}=0.73)$. In addition, ERT and WRT diets at $<4 \mathrm{~m}$ depth overlapped with that of $O$. hatcheri to a lesser extent ( $\mathrm{SI}=0.50$ and 0.48 , respectively), as happened between WRT, $S$. trutta and P. trucha at $10-50 \mathrm{~m}$ depth (SIs between 0.49 and 0.58). Levins' measure of niche breadth was higher for ERT $\left(B^{\prime}=0.41\right)$ than for WRT $\left(B^{\prime}=0.25\right)$, mainly due to ingestion of indigestible items (Tab. 2; Fig. 5). The broadest niche was that of $S$. trutta $\left(B^{\prime}=0.50\right)$. At the other extreme, O. hatcheri showed the most specialized trophic niche $\left(B^{\prime}=0.15\right)$, followed by $P$. trucha $\left(B^{\prime}=0.28\right)$. The $S$. salar $B^{\prime}$ value of 0.17 is probably not representative since it is based on only 2 individuals. 

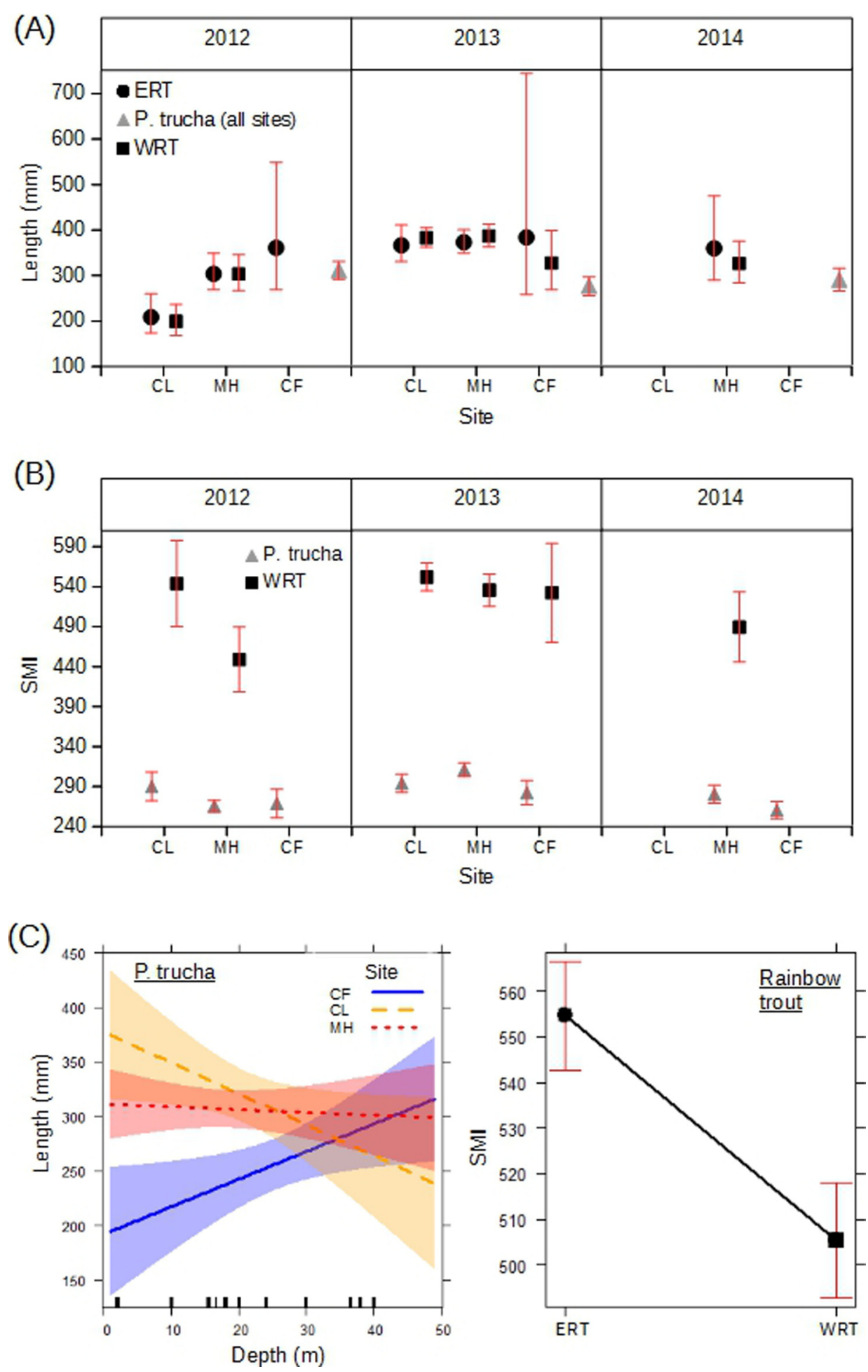

Fig. 4. GLM estimates of (A) length $v$ s. site by year for ERT, WRT, and Percichthys trucha, the latter with sites not differentiated (factor not present in its final model), (B) SMI vs. site by year for WRT and P. trucha, and (C) length $v s$. depth by site for P. trucha and SMI vs. origin of rainbow trout (escaped/wild). Bars and ribbons represent 95\% confidence intervals. Additional ticks indicate sampling depths.

Diet analysis with DA generated four significant DFs $(p<0.005)$. The first of these allowed discrimination of $P$. trucha and S. trutta from $O$. hatcheri, ERT and WRT, on the basis of the amount of decapod crustacea and immature aquatic insects for the former species group, and terrestrial insects for the latter. The DF2 identified $S$. trutta by their consumption of big fish (mainly P. trucha), pumice stones, and rodents, while DF3 did the same with $O$. hatcheri, as they prey on snails. DF4 separated ERT from WRT, with the former characterized by their consumption of plant and synthetic fragments, and the latter by terrestrial insects (see Appendix 3 for DA output). 


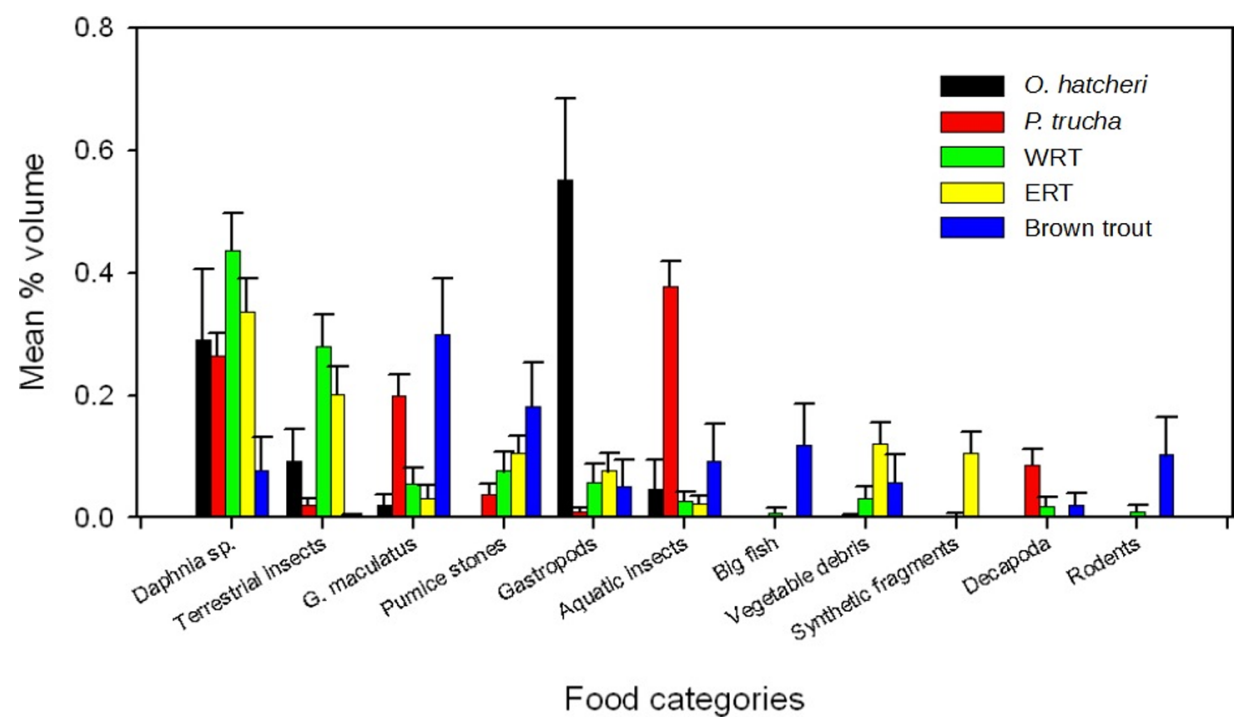

Fig. 5. Average of volume percentages (mean $\%$ volume) indicating prey ( $\times$ axis) and predator (fill pattern). Bars indicate mean and standard error.

Table 2. Schoener index of between-species diet overlap at $<4 \mathrm{~m}$ (top-right) and at $10-50 \mathrm{~m}$ depth (bottom-left). Standarized Levins' measure of diet breadth is shown in the last row. Light gray cells indicate cases with low number of individuals $(N=2)$. Dashes indicate no samples collected.

\begin{tabular}{lcccccc}
\hline & O. hatcheri & P. trucha & WRT & ERT & $\begin{array}{c}\text { Brown } \\
\text { trout }\end{array}$ & $\begin{array}{c}\text { Atlantic } \\
\text { salmon }\end{array}$ \\
\hline O. hatcheri & & 0.23 & 0.48 & 0.50 & 0.11 & - \\
$P$. trucha & - & & 0.30 & 0.27 & 0.20 & - \\
WRT & - & 0.55 & & 0.73 & 0.26 & - \\
ERT & - & 0.29 & 0.43 & & 0.36 & - \\
Brown trout & - & 0.49 & 0.58 & 0.08 & & - \\
Atlantic salmon & - & 0.46 & 0.58 & 0.22 & 0.45 & \\
Diet breadth (Levins) & 0.15 & 0.28 & 0.25 & 0.41 & 0.50 & 0.17 \\
\hline
\end{tabular}

Differences between species for the DF values were found at $<4 \mathrm{~m}$ depth (Kruskal-Wallis, $p<0.05$ ), where each species pair was differentiated (Dunn's test, $p<0.05$ ) by some DF, except for ERT and WRT (Dunn's test, $p>0.05$ ). At more than $4 \mathrm{~m}$, there was no significant difference found in any of the pairwise comparisons between species (Dunn's test, $p>0.05$ ) (see Appendix 3), although the low capture numbers of some species in that stratum may limit the power of diet comparisons.

Empty stomachs $(N=53)$ represented $16.3 \%$ of total stomachs analyzed. Percentages of empty stomachs for each species were $10 \%$ for ERT, $13 \%$ for WRT, $22 \%$ for $S$. trutta, $0 \%$ for $S$. salar, $20 \%$ for P. trucha, and $9 \%$ for $O$. hatcheri, from totals of $68,68,27,2,148$, and 11 stomachs analyzed, respectively. Proportions of empty stomachs were not significantly different between the species evaluated (GLM, $p>0.05$ ).

\section{Discussion}

The goal of this work was to assess the spatial distribution and trophic interactions of a native-exotic fish community in a reservoir with 25 years of salmonid cage-culture. Pronounced vertical segregation was observed between the two most abundant species, i.e. the exotic rainbow trout (both farm escapees and wild) and the native $P$. trucha, the former dominating at shallow depths and the latter at greater depths. Escaped (ERT) and wild (WRT) rainbow trout each accounted for $c$. one third of the total littoral capture $(<4 \mathrm{~m})$, coinciding with other studies on depth distribution of farm escapees (Chittenden et al., 2011; Skilbrei, 2012; Patterson and Blanchfield, 2013). Diet differences between species were marked, paralleling the observed segregation by depth. However, the low piscivory-benthivory of rainbow trout and the high incidence of zooplankton consumption across all species contrasted with the usual trophic relationships observed in other lakes and reservoirs of Andean Patagonia (Macchi et al., 1999, 2007; Juncos et al., 2014; Arcagni et al., 2015).

This study was restricted to late summer and early autumn and some patterns are expected to vary across seasons. Since adult salmonids are expected to migrate to affluent rivers during the reproductive season (winter-spring), their abundance in the littoral of the reservoir may decrease in these months. In the case of $P$. trucha, increased abundance of reproductive fish in shallow water is expected from spring to early summer (Buria et al., 2007; Aigo, 2010; Juncos et al., 2014), seasons we did not sample. However, our results showed an intense vertical segregation that suggests strong 
negative interactions between $P$. trucha and rainbow trout. Prey availability is also expected to change across seasons. For instance, juvenile recruitment of $G$. maculatus to the littoral occurs in late summer and early autumn (Barriga et al., 2002, 2007; Juncos et al., 2014), and more abundant terrestrial insects are expected in spring and summer (Juncos et al., 2014). Therefore, these changes would reduce the low incidence of $G$. maculatus in rainbow trout diet, and intensify its differences with $P$. trucha, as it consumes greater proportions of terrestrial insects, a prey group not generally important for P. trucha (Macchi et al., 1999; Juncos et al., 2014).

The abundance of $P$. trucha at shallow depths in Patagonian lakes seems to vary across seasons according to its breeding cycle (Buria et al., 2007; Macchi et al., 2007; Aigo, 2010; Juncos et al., 2014), with higher presence of mature individuals in shallow waters in spring and early summer. Therefore, the low relative abundance of $P$. trucha observed here in the littoral zone from late summer to early autumn represents the non-reproductive season, when deeper habits are more common.

Worthy of note are two patterns that stood out in the Alicurá reservoir from an earlier study (Cussac et al., 2014) as well as from our results: (1) null summer-autumn captures of $P$. trucha at $<4$ m depth are the norm, and (2) negligible habitat use overlap of $P$. trucha and rainbow trout occurs in medium to high depths, as the latter concentrates markedly at $<4 \mathrm{~m}$ depth. However, in Patagonian lakes it has been observed that rainbow trout shares deep habitats extensively with $P$. trucha in autumn, with some $P$. trucha remaining in the littoral in nonreproductive periods, although with lower abundances (Macchi et al., 2007; Juncos et al., 2014). The strong spatial segregation between $P$. truch $a$ and rainbow trout intensified in Alicurá reservoir following the onset of aquaculture 25 years ago, also characterized by the almost total absence of O. hatcheri in littoral captures (Cussac et al., 2014). This outcome may be a consequence of negative interactions taking place between the native fish and farm escapees, as has been argued for Chilean lakes (Arismendi et al., 2009).

The lack of littoral macrophytes due to water level fluctuations, which in the Alicurá reservoir are relatively small (i.e. $<4.5 \mathrm{~m}$, compared to Valdovinos et al., 2007; Zohary and Ostrovsky, 2011; Eloranta et al., 2016), is expected to reduce occupation of the littoral zone by native species in the presence of the introduced rainbow trout (Hanisch et al., 2012; Otturi et al., 2016). However, the abundant large rocks and semisubmerged coastal trees present in the Alicurá reservoir seem to provide the necessary structure and refugia for native species, as revealed by the observation of $P$. trucha less than $10 \mathrm{~cm}$ in length using the shallow littoral in protected bays, along with G. maculatus and juvenile ERT (D. Nabaes Jodar, unpublished data).

Our results suggest that ERT and WRT differed in their functional roles in the reservoir, i.e. diet (ERT consuming synthetic material and debris), body condition/shape (ERT heavier at the same length) and site differences in relative abundance (WRT was more represented near tributaries - CL site - than at the farms - MH site). Assessment of fish origin (wild/farmed) is sometimes affected by the partial regeneration of eroded fins of farm escapees (Latremouille, 2003; Fiske et al., 2005; Hoyle et al., 2007). For S. salar, Green et al.
(2012) found that external assessment of farmed $v s$. wild origin were generally efective, with higher chance of wrongly classifying true farmed individuals as wild than true wild individuals as farmed. Johnston and Wilson (2014), studying ERT in a Canadian lake, found a similar fashion of correct classification by visual assessment $(85 \%$, compared to genetic analysis). A lower overall precision was reported for rainbow trout in Chile (Consuegra et al., 2011). Therefore, it is reasonable to assume some degree of overestimation of wild individuals at the expense of farmed rainbow trout in our data.

Variations between the three sampling years were found for several measures, which were probably associated with environmental conditions. Severe ash deposition from the Puyehue-Cordon Caulle volcanic complex eruption affected the region just 8 months before our 2012 sampling periods (Gaitán et al., 2011). Also, water level of the reservoir on both 2012 sampling dates was lower than in April 2013 and March 2014. In 2012, greater proportions of $P$. trucha at $<4 \mathrm{~m}$ depth were found than in 2013 (with total absence of $P$. trucha at $<4 \mathrm{~m}$, as in 2014), and the opposite pattern was observed for rainbow trout. In addition, $P$. truch $a$ were larger in 2012 than in 2013, in contrast to the pattern shown by ERT and WRT (statistically significant only at some sites). We argue that P. trucha, being a native fish, has a greater capacity to cope with ash deposition than exotic salmonids. Furthermore, a decrease in the reservoir water level reduces available habitat, which in this case favored the presence of $P$. trucha at shallow depths in the 2012 samplings.

Diet habits reflected the observed vertical distribution as well as group-specific patterns. Daphnia, characterized by diel vertical migrations (Alonso et al., 2004; Reissig et al., 2004), was the most evenly consumed item (except for $S$. trutta), representing the main driver of diet overlap between species. Terrestrial insects were important for littoral dwellers (i.e. rainbow trout), whereas forage fish were for species using deep strata (i.e. S. trutta and P. trucha). Benthic immature insects and snails characterized P. trucha and $O$. hatcheri diets, respectively. Finally, consumption of indigestible floating items differentiated ERT from WRT.

Feeding habits of ERT differ among studies around the world. Two studies in Norwegian sea fjords reported numerous indigestible items in ERT stomach contents with less than a year in the wild, but not farm pellets or wild food (Rikardsen and Sandring, 2006; Skilbrei, 2012). Wild food and farm pellets, but not indigestible items, were found in ERT with probably more than a year since escape time in Chilean sea fjords (Soto et al., 2001) and lakes (Arismendi et al., 2009). In a semi-enclosed estuarine habitat in Tasmania, ERT consumed mainly farm pellets and indigestible items, but also small amounts of wild food, depending on time since escape (Abrantes et al., 2011). These cases highlight the importance of time since escape in the feeding behavior of ERT. In the Canadian lake Huron, normal growth of ERT recaptured next to and distant $(500 \mathrm{~m})$ from farms suggested consumption of wild food and/or farm pellets (Patterson and Blanchfield, 2013). In addition, stable isotope analysis showed that ERT captured in tributaries of this lake consumed wild prey, resembling WRT isotopic signals (Johnston and Wilson, 2014). In Alicurá reservoir ERT consumed indigestible items as well as wild food, but not farm pellets. However, our sampling site in the farm area was located at $c .900 \mathrm{~m}$ from the 
closest farm, which could reduce the chances of capturing fish with undigested pellets in their stomachs. The time since escape of our recaptured ERTs is variable, but potentially much longer than 1 year. Farm escapees could affect wild fish behavior. Given that fish learn from the behavior and chemical cues of other fishes (Brown et al., 2003; Webster et al., 2008), the surface feeding and spatial use typical of rainbow trout farm escapees (Chittenden et al., 2011; Skilbrei, 2012; Patterson and Blanchfield, 2013) may influence the behavior of conspecifics, particularly those naïve fishes reaching the reservoir after birth in tributaries. In oligotrophic environments like those in Patagonia, where wild fish biomass is low (Quirós, 1990), the effect of the massive and sustained input of farm escapees on wild fish behavior is likely to be important, favoring a surface restricted distribution.

Potential competition between $O$. hatcheri and rainbow trout is considerable, as they share their main food items. Although both species fed extensively on Daphnia, O. hatcheri consumed more snails, and less terrestrial insects, whereas rainbow trout showed the opposite pattern. This difference could be the consequence of the stenophagous character of adult $O$. hatcheri (Crichigno et al., 2012), past competition leading to trophic and spatial segregation (i.e. less pelagic, more littoral-benthic habits for $O$. hatcheri), and/or the result of $O$. hatcheri abandoning the western side of the reservoir (sites MH and CL; Cussac et al., 2014 and present results) where coasts are forested and abundance of terrestrial insects (hemipterans of the exotic Pinus spp.) would be increased. The study of the ecology of $O$. hatcheri is hampered by its present low abundance (Macchi et al., 2007; Juncos et al., 2014), which we argue has been accentuated in Alicurá reservoir by the impact of fish escapees (Cussac et al., 2014), as suggested for other species in Chilean lakes (Arismendi et al., 2009).

Freshwater rainbow trout feeding habits often include piscivory, benthivory and/or zooplanktivory (Galbraith, 1967; Elser et al., 1995; Negus and Hoffman, 2013; Monroy et al., 2014). Although the high trophic diversity of salmonids and more specialized diets of native fishes observed in Nahuel Huapi lake (Juncos et al., 2014) was evident in the Alicurá Reservoir, we found very low piscivory and benthivory for rainbow trout (c. 5\% each). This contrasts with previous studies performed in this reservoir (Macchi et al., 1999), in the two headwater lakes Traful (Vigliano et al., 2008) and Nahuel Huapi (Juncos et al., 2014; Arcagni et al., 2015), in the adjacent Ramos Mexía reservoir (Ferriz, 1988), and in Chilean lakes (Arismendi et al., 2009). Indeed, large zooplankton is the main food item for rainbow trout in Alicurá reservoir (and the second most important for P. trucha), suggesting an in situ shift from past benthivory (Macchi et al., 1999) to present zooplanktivory.

Studies of aquaculture impacts on freshwater zooplankton are scarce and have shown contrasting results so far (Guo and Li, 2003; Podemski and Blanchfield, 2006; Paterson et al., 2010). Considering that the abundance and growth of Daphnia in Patagonian lakes is limited mainly by phosphorous (Balseiro et al., 2007), our fish stomach content data suggest an increase in the availability of this crustacean in the Alicurá reservoir, which may be a delayed consequence of nutrient discharges from aquaculture activities (Temporetti et al., 2001).
At sites MH and CL, native $P$. trucha were larger (only at shallow depths) and had higher body condition (SMI; only in year 2013) than at CF. This pattern could be favored by enhanced prey availability near the farms, as has been suggested for Canadian lakes (Podemski and Blanchfield, 2006). The comparison of body shape to assess nutritional status between farmed escapees and their free-living conspecifics is known to be affected by shape differences resulting from particular rearing environment and genetics (Swain et al., 1991; Jonsson and Jonsson, 2006; Consuegra et al., 2011). In this regard, our results showed a deeper body shape (higher body condition, SMI) for ERT compared to WRT.

The capacity of farmed escapees to colonize wild environments has already been described in other ecosystems (e.g. Soto et al., 2001; Podemski and Blanchfield, 2006; Arismendi et al., 2009; Consuegra et al., 2011; Johnston and Wilson, 2014). Recent captures of mature ERT more than $30 \mathrm{~km}$ upstream in the main affluent of Alicurá reservoir (D. Nabaes Jodar, unpublished data), suggest that ERT is an expanding component of the regional fish community.

In conclusion, our results demonstrated that aquaculture activities may have a considerable impact on the Alicurá reservoir community by altering the spatial and trophic niche used by fish. These alterations seem to be the result of farm fish escapes and nutrient pollution at different levels of the trophic web. The higher condition of $P$. trucha close to the farms, as well as the unprecedented high incidence of the phosphorus-dependent Daphnia in fish stomachs, suggest that farm nutrient discharges have had a significant impact on this ecosystem. Last, but not least, the potential upstream colonization of escapees deserves to be addressed as this could affect the biodiversity and wild fish populations of Patagonian rivers and lakes.

Acknowledgements. The following institutions are gratefully acknowledged for funding the present project: Universidad Nacional del Comahue (04B181) and CONICET (PIP $11220120100063 \mathrm{CO}$ ), Argentina. We are very grateful for the valuable comments and proposals from three anonymous reviewers who helped us to improve the paper.

\section{References}

Abrantes KG, Lyle JM, Nichols PD, Semmens JM. 2011. Do exotic salmonids feed on native fauna after escaping from aquaculture cages in Tasmania, Australia? Can J Fish Aquat Sci 68: 1539-1551.

Ahlbeck I, Hansson S, Hjerne O. 2012. Evaluating fish diet analysis methods by individual-based modeling. Can J Fish Aquat Sci 69: 1184-1201.

Aigo J. 2010. Interacción entre peces nativos y salmónidos en Patagonia: su vulnerabilidad al cambio climático, Doctoral thesis. Argentina: Universidad Nacional del Comahue.

Aigo J, Cussac V, Peris S, et al. 2008. Distribution of introduced and native fish in Patagonia (Argentina): patterns and changes in fish assemblages. Rev Fish Biol Fish 18: 387-408.

Alonso C, Rocco V, Barriga JP, Battini MA, Zagarese H. 2004. Surface avoidance by freshwater zooplankton: field evidence on the role of ultraviolet radiation. Limnol Oceanogr 49: 225-232.

Arcagni M, Rizzo A, Campbell LM, et al. 2015. Stable isotope analysis of trophic structure, energy flow and spatial variability in a 
large ultraoligotrophic lake in Northwest Patagonia. $J$ Great Lakes Res 41: 916-925.

Arismendi I, Soto D, Penaluna B, Jara C, Leal C, León-Muñoz J. 2009. Aquaculture, non-native salmonid invasions and associated declines of native fishes in Northern Patagonian lakes. Freshw Biol 54: $1135-1147$.

Balseiro E, Modenutti B, Queimaliños C, Reissig M. 2007. Daphnia distribution in Andean Patagonian lakes: effect of low food quality and fish predation. Aquat Ecol 41: 599-609.

Barriga JP, Battini MA, Macchi PJ, Milano D, Cussac VE. 2002. Spatial and temporal distribution of landlocked Galaxias maculatus and Galaxias platei (Pisces: Galaxiidae) in a lake in the South American Andes. New Zeal J Mar Fresh Res 36: 349-363.

Barriga JP, Battini MA, Cussac VE. 2007. Annual dynamics variation of landlocked Galaxias maculatus (Jenyns 1842) population in a northern Patagonian river: occurrence of juvenile upstream migration. $J$ Appl Ichthyol 23: 128-135.

Bourret V, O'Reilly PT, Carr JW, Berg PR, Bernatchez L. 2011. Temporal change in genetic integrity suggests loss of local adapta tion in a wild Atlantic salmon (Salmo salar) population following introgression by farmed escapees. Heredity 106: 500-510.

Bridger CJ, Booth RK, McKinley RS, Scruton DA. 2001. Site fidelity and dispersal patterns of domestic triploid steelhead trout (Oncorhynchus mykiss Walbaum) released to the wild. ICES $J$ Mar Sci 58: 510-516.

Bristow CE, Morin A, Hesslein RH, Podemski CL. 2008. Phosphorus budget and productivity of an experimental lake during the initial three years of cage aquaculture. Can J Fish Aquat Sci 65: 2485-2495.

Brown C, Markula A, Laland K. 2003. Social learning of prey loca tion in hatchery-reared Atlantic salmon. J Fish Biol 63: 738-745.

Bureau DP, Hua K. 2010. Towards effective nutritional management of waste outputs in aquaculture, with particular reference to salmonid aquaculture operations. Aquacult Res 41: 777-792.

Buria L, Walde SJ, Battini M, et al. 2007. Movement of a South American perch Percichthys trucha in a mountain Patagonian lake during spawning and prespawning periods. J Fish Biol 70: 215-230.

Chittenden C, Rikardsen A, Skilbrei O, et al. 2011. An effective method for the recapture of escaped farmed salmon. Aquacult Environ Interact 1: 215-224.

Consuegra S, Phillips N, Gajardo G, García de Leaniz C. 2011. Winning the invasion roulette: escapes from fish farms increase admixture and facilitate establishment of non-native rainbow trout. Evol Appl 4: 660-671.

Crichigno SA, Battini MA, Cussac VE. 2012. Early morphological variation and induction of phenotypic plasticity in Patagonian pejerrey. Neotrop Ichthyol 10: 341-348.

Cussac VE, Ruzzante D, Walde S, et al. 1998. Body shape variation of three species of Percichthys in relation to their coexistence in the Limay River, in northern Patagonia. Environ Biol Fish 53: 143-153.

Cussac VE, Becker LA, Aigo J, et al. 2014. Abundance of native fishes, wild-introduced salmonids and escaped farmed rainbow trout in a Patagonian reservoir. Lake Reserv Manag 19: 74-85.

dos Santos RM, Rocha GS, Rocha O, Santos Wisniewski MJ. 2009. Influence of net cage fish cultures on the diversity of the zooplankton community in the Furnas hydroelectric reservoir, Areado, MG, Brazil. Aquac Res 40: 753-761.

Eloranta AP, Sánchez-Hernández J, Amundsen PA, et al. 2016. Water level regulation affects niche use of a lake top predator, Arctic charr (Salvelinus alpinus). Ecohydrology 10: 1-9.
Elser JT, Luecke C, Brett MT, Goldman CR. 1995. Effects of food web compensation after manipulation of rainbow trout in an oligotrophic lake. Ecology 76: 52-69.

Ferriz RA. 1988. Relaciones tróficas de Trucha Marrón, Salmo fario Linné, y Trucha Arco Iris, Salmo gairdneri Richardson (Osteichthyes, Salmoniformes) en un embalse norpatagónico. Stud Neotrop Fauna E 23: 123-131.

Findlay DL, Podemski CL, Kasian SEM. 2009. Aquaculture impacts on the algal and bacterial communities in a small boreal forest. Can J Fish Aquat Sci 66: 1936-1948.

Fiske P, Lund RA, Hansen LP. 2005. Identifying fish farm escapees. In: Cadrin SX, Friedland KD, Waldman JD, eds. Stock identification methods. Amsterdam: Elsevier Academic Press, pp. 659-680.

Fox J. 2003. Effect displays in R for generalised linear models. $J$ Stat Softw 8: 1-27.

Fox J, Weisberg S. 2011. An R companion to applied regression, 2nd ed. Thousand Oaks: Sage, 449 p.

Gaitán JJ, Ayesa JA, Umaña F, Raffo F, Bran DB. 2011. Cartografía del área afectada por la ceniza del volcán puyehue en Río Negro y Neuquén. In: XIX Congreso Latinoamericano de la ciencia del suelo, XXIII Congreso Aregntino de la ciencia del suelo.

Galbraith MG Jr. 1967. Size-selective predation on Daphnia by rainbow trout and yellow perch. Trans Am Fish Soc 96: 1-10.

Green DM, Penman DJ, Migaud H, Bron JE, Taggart JB, McAndrew BJ. 2012. The impact of escaped farmed Atlantic Salmon (Salmo salar L.) on catch statistics in Scotland. PLoS ONE 7: 1-9.

Guo L, Li Z. 2003. Effects of nitrogen and phosphorus from fish cageculture on the communities of a shallow lake in middle Yangtze River basin of China. Aquaculture 226: 201-212.

Habit E, Piedra P, Ruzzante DE, et al. 2010. Changes in the distribution of native fishes in response to introduced species and other anthropogenic effects. Global Ecol Biogeogr 19: 697-710.

Hanisch JR, Tonn WM, Paszkowski CA, Scrimgeour GJ. 2012. Complex littoral habitat influences the response of native minnows to stocked trout: evidence from whole-lake comparisons and experimental predator enclosures. Can JFish Aquat Sci 69: 273-281.

Hindar K, Fleming IA. 2007. Behavioral and genetic interactions between escaped farm salmon and wild Atlantic salmon. In: Bert $\mathrm{TM}$, ed. Ecological and genetic implications of aquaculture activities. Berlin: Springer, pp. 115-122.

Hothorn T, Bretz F, Westfall P. 2008. Simultaneous inference in general parametric models. Biom J 50: 346-363.

Hoyle I, Oidtmann B, Ellis T, et al. 2007. A validated macroscopic key to assess fin damage in farmed rainbow trout (Oncorhynchus mykiss). Aquaculture 270: 142-148.

Hyslop EJ. 1980. Stomach content analysis - a review of methods and their application. J Fish Biol 17: 411-429.

Johnston TA, Wilson CC. 2014. Comparative ecologies of domestic and naturalised rainbow trout in northern Lake Huron. Ecol Freshw Fish 24: 338-354.

Johnston TA, Keir M, Power M. 2010. Response of native and naturalized fish to salmonid cage culture farms in northern Lake Huron, Canada. Trans Am Fish Soc 139: 660-670.

Jonsson B, Jonsson N. 2006. Cultured Atlantic salmon in nature: a review of their ecology and interaction with wild fish. ICES J Mar Sci 63: 1162-1181.

Juncos R, Milano D, Macchi PJ, Vigliano PH. 2014. Niche segregation facilitates coexistence between native and introduced fishes in a deep Patagonian lake. Hydrobiologia 743: 53-67.

Latremouille DN. 2003. Fin erosion in aquaculture and natural environments. Rev Fish Sci 11: 315-335. 
Levins R. 1968. Evolution in changing environments. Princeton, NJ, USA: Princeton University Press.

López-Albarello A. 2004. Taxonomy of the genus Percichthys (Perciformes: Percichthyidae). Ichthyol Explor Freshw 15: 331-350.

Macchi PJ, Cussac VE, Alonso MF, Denegri MA. 1999. Predation relationships between introduced salmonids and the native fish fauna in lakes and reservoirs in Northern Patagonia. Ecol Freshw Fish 8: 227-236.

Macchi PJ, Pascual MA, Vigliano PH. 2007. Differential piscivory of the native Percichthys trucha and exotic salmonids upon the native forage fish Galaxias maculatus in Patagonian Andean lakes. Limnologica 37: 76-87.

Maceda-Veiga A, Green AJ, De Sostoa A. 2014. Scaled body-mass index shows how habitat quality influences the condition of four fish taxa in north-eastern Spain and provides a novel indicator of ecosystem health. Freshw Biol 59: 1145-1160.

Marshall S, Elliott M. 1997. A comparison of univariate and multivariate numerical and graphical techniques for determining inter- and intraspecific feeding relationships in estuarine fish. J Fish Biol 51: 526-545.

McGinnity P, Prodöhl P, Ferguson A, et al. 2003. Fitness reduction and potential extinction of wild populations of Atlantic salmon, Salmo salar, as a result of interactions with escaped farm salmon. Proc Biol Sci 270: 2443-2450.

Monroy M, Maceda-Veiga A, Caiola N, De Sostoa A. 2014. Trophic interactions between native and introduced fish species in a littoral fish community. J Fish Biol 85: 1693-1706.

Muñoz-Ramírez CP, Unmack PJ, Habit E, Johnson JB, Cussac VE, Victoriano P. 2014. Phylogeography of the ancient catfish family Diplomystidae: biogeographic, systematic, and conservation implications. Mol Phylogenet Evol 73: 146-160.

Naylor R, Hindar K, Fleming IA, et al. 2005. Fugitive salmon: assessing the risks of escaped fish from net-pen aquaculture. BioScience 55: 427-237.

Negus MT, Hoffman JC. 2013. Habitat and diet differentiation by two strains of rainbow trout in Lake Superior based on archival tags, stable isotopes, and bioenergetics. J Great Lakes Res 39: 578-590.

Norusis MJ. 1986. SPSS/PC+ advanced statistics. Chicago, IL: SPSS Inc.

Olaussen JO, Liu Y. 2011. On the willingness-to-pay for recreational fishing escaped farmed versus wild atlantic salmon. Aquacult Econ Manag 15: 245-261.

Otturi MG, Battini MA, Barriga JP. 2016. The effects of invasive rainbow trout on habitat use and diel locomotor activity in the South American Creole perch: an experimental approach. Hydrobiologia 777: 243-254.

Pascual MA, Cussac V, Dyer B, et al. 2007. Freshwater fishes of Patagonia in the 21 st century after a hundred years of human settlement, species introductions, and environmental change. Aquat Ecosyst Health Manag 10: 212-227.

Pascual MA, Lancelotti JL, Ernst B, Ciancio JE, Aedo E, GarcíaAsorey M. 2009. Scale, connectivity, and incentives in the introduction and management of non-native species: the case of exotic salmonids in Patagonia. Front Ecol Environ 7: 533-540.

Paterson MJ, Podemski CL, Findlay WJ, Findlay DL, Salki AG. 2010. The response of zooplankton in a whole-lake experiment on the effects of a cage aquaculture operation for rainbow trout (Oncorhynchus mykiss). Can J Fish Aquat Sci 67: 1852-1861.

Patterson K, Blanchfield P. 2013. Oncorhynchus mykiss escaped from commercial freshwater aquaculture pens in Lake Huron, Canada. Aquacult Environ Interact 4: 53-65.
Peig J, Green AJ. 2009. New perspectives for estimating body condition from mass/length data: the Scaled Mass Index as an alternative method. Oikos 118: 1883-1891.

Podemski CL, Blanchfield PJ. 2006. Overview of the environmental impacts of Canadian freshwater aquaculture. In: Paradis S, Smith D, Chevrier A, eds. A scientific review of the potential environmental effects of aquaculture in aquatic ecosystems. Ottawa: Fisheries and Oceans Canada, pp. 30-79.

Quirós R. 1990. Predictors of relative fish biomass in lakes and reservoirs of Argentina. Can J Fish Aquat Sci 47: 928-939.

R Core Team. 2015. R: a language and environment for statistical computing. Vienna, Austria: R Foundation for Statistical Computing.

Reid GK, McMillan I, Moccia RD. 2006. Near-field loading dynamics of total phosphorus and short-term water quality variations at a rainbow trout cage farm in Lake Huron. $J$ Environ Monit 8: 947-954.

Reissig M, Modenutti B, Balseiro E, Queimaliños C. 2004. The role of the predaceous copepod Parabroteas sarsi in the pelagic food web of a large deep Andean lake. Hydrobiologia 524: 67-77.

Rikardsen AH, Sandring S. 2006. Diet and size-selective feeding by escaped hatchery rainbow trout Oncorhynchus mykiss (Walbaum). ICES J Mar Sci 63: 460-465.

Ruzzante DE, Walde SJ, Cussac VE, et al. 2006. Phylogeography of the Percichthyidae (Pisces) in Patagonia: roles of orogeny, glaciation, and volcanism. Mol Ecol 15: 2949-2968.

Ruzzante DE, Walde SJ, Macchi PJ, Alonso M, Barriga JP. 2011. Phylogeography and phenotypic diversification in the Patagonian fish Percichthys trucha: the roles of Quaternary glacial cycles and natural selection. Biol J Linn Soc 103: 514-529.

Skaala Ø, Wennevik V, Glover KA. 2006. Evidence of temporal genetic change in wild Atlantic salmon, Salmo salar L., populations affected by farm escapees. ICES J Mar Sci 63: 1224-1233.

Skilbrei OT. 2010. Adult recaptures of farmed Atlantic salmon postsmolts allowed to escape during summer. Aquacult Environ Interact 1: 147-153.

Skilbrei OT. 2012. The importance of escaped farmed rainbow trout (Oncorhynchus mykiss) as a vector for the salmon louse (Lepeophtheirus salmonis) depends on the hydrological conditions in the fjord. Hydrobiologia 686: 287-297.

Soto D, Jara F, Moreno C. 2001. Escaped salmon in the inner seas, southern Chile: facing ecological and social conflicts. Ecol Appl 11: $1750-1762$.

Sterner RW, Schulz KL. 1998. Zooplankton nutrition: recent progress and a reality check. Aquat Ecol 32: 261-279.

Swain DP, Riddell BE, Murray CB. 1991. Morphological differences between hatchery and wild populations of coho salmon (Oncorhynchus kisutch): environmental versus genetic origin. Can J Fish Aquat Sci 48: 1783-1791.

Temporetti PF, Alonso MF, Baffico G, et al. 2001. Trophic state, fish community and intensive production of salmonids in Alicurá Reservoir (Patagonia, Argentina). Lake Reserv Manage 6: 259-267.

Valdovinos C, Moya C, Olmos V, Parra O, Karrasch B, Buettner O. 2007. The importance of water-level fluctuation for the conservation of shallow water benthic macroinvertebrates: an example in the Andean zone of Chile. Biodivers Conserv 16: 3095-3109.

Vigliano PH, Alonso MF, Aquaculture M. 2007. Salmonid introductions in Patagonia: a mixed blessing. In: Bert TM, ed. Ecological and genetic implications of aquaculture activities. Berlin: Springer, pp. 315-331.

Vigliano PH, Macchi PJ, Alonso M, Denegri MA, García Asorey M, Lippolt G. 2008. Gill net and hydroacoustic fish resource 
D.N. Nabaes Jodar et al.: Knowl. Manag. Aquat. Ecosyst. 2017, 418, 33

evaluation of an ultraoligotrophic lake of northern Patagonia Argentina. Am Fish Soc Symp 49: 1725-1747.

Wallace RK Jr. 1981. An assessment of diet-overlap indexes. Trans Am Fish Soc 110: 37-41.

Warton DI, Hui FKC. 2011. The arcsine is asinine: the analysis of proportions in ecology. Ecology 92: 3-10.

Webster MM, Ward AJW, Hart PJB. 2008. Shoal and prey patch choice by co-occurring fishes and prawns: inter-taxa use of socially transmitted cues. Proc R Soc B 275: 203-208.
Wickham H. 2009. ggplot2: elegant graphics for data analysis. New York: Springer-Verlag.

Zeller N, Avila CD, Núnez P. 2009. Acuicultura. Documento sectorial integral. Provincia del Neuquén, Argentina: Ministerio de Desarrollo Territorial.

Zohary T, Ostrovsky I. 2011. Ecological impacts of excessive water level fluctuations in stratified lakes. Inland Waters 1: 47-59.

Zuur AF, Ieno EN, Walker NJ, Saveliev AA, Smith G. 2009. Mixed effects models and extensions in ecology with R. New York: Springer.

Cite this article as: Nabaes Jodar DN, Becker LA, Cordero P, Blasetti G, Cussac VE. 2017. Native and exotic fishes in a Patagonian reservoir with rainbow trout cage culture: spatial and trophic resource use. Knowl. Manag. Aquat. Ecosyst., 418, 33. 


\section{Appendices}

Appendix 1. Sampling data: date, site, depth, and mesh size of gillnets used. The sites were: (1) Malalhuaca (MH), located in the trout farm area, at c. $900 \mathrm{~m}$ from the nearest one; (2) Cola Limay (CL), $1500 \mathrm{~m}$ upstream of (southward) the southernmost farm; and (3) Coloradas Fondo (CF), $25 \mathrm{~km}$ downstream (northward) from the northernmost farm.

\begin{tabular}{llll}
\hline Date & Site & Depth $(\mathrm{m})$ & Bar mesh size $(\mathrm{mm})$ \\
\hline February 2012 &,- MH, & $<4,20,40$ & $15,20,30,50,60,70(10 \mathrm{~m} \mathrm{length} \mathrm{each)}$ \\
March 2012 & CL, MH, CF & $<4,20,40$ & $15,21,25,30,35,38,52(25 \mathrm{~m} \mathrm{length} \mathrm{each)}$ \\
April 2013 & CL, MH, CF & $<4,20,40$ & $15,21,25,30,35,38,52(25 \mathrm{~m}$ length each) \\
March 2014 &,- MH, CF & $<4,10,30,40,50$ & $15,20,30,50,60,70(10 \mathrm{~m}$ length each) \\
\hline
\end{tabular}

Appendix 2. Relative abundances (number of individuals in brackets) by site (CL: Cola Limay, MH: Malalhuaca, CF: Coloradas Fondo), date of capture and depth $(\mathrm{m})$. Bottom rows show mean length and range, and number of guts with content indicated by species. ERT: Escaped Rainbow Trout. WRT: wild rainbow trout.

\begin{tabular}{|c|c|c|c|c|c|c|c|c|c|}
\hline Site & Date & Depth (m) & ERT & WRT & Brown trout & Atlantic salmon & P. trucha & O. hatcheri & G. platei \\
\hline \multirow{6}{*}{ CL } & \multirow{3}{*}{ March 2012} & 2 & $60(6)$ & $30(3)$ & $0(0)$ & $0(0)$ & $10(1)$ & $0(0)$ & $0(0)$ \\
\hline & & 20 & $0(0)$ & $20(1)$ & $0(0)$ & $0(0)$ & $80(4)$ & $0(0)$ & $0(0)$ \\
\hline & & 40 & $0(0)$ & $0(0)$ & $0(0)$ & $0(0)$ & $100(3)$ & $0(0)$ & $0(0)$ \\
\hline & \multirow{3}{*}{ April 2013} & 2 & $31(18)$ & $62(36)$ & $7(4)$ & $0(0)$ & $0(0)$ & $0(0)$ & $0(0)$ \\
\hline & & 15.5 & $10(2)$ & $0(0)$ & $17(3)$ & $6(1)$ & 67 (12) & $0(0)$ & $0(0)$ \\
\hline & & 24 & $0(0)$ & $10(1)$ & $0(0)$ & $10(1)$ & $80(8)$ & $0(0)$ & $0(0)$ \\
\hline \multirow{14}{*}{ MH } & \multirow{4}{*}{ February 2012} & 2 & $4(1)$ & $13(3)$ & $4(1)$ & $0(0)$ & 79 (19) & $0(0)$ & $0(0)$ \\
\hline & & 20 & $0(0)$ & $0(0)$ & $15(4)$ & $0(0)$ & $85(23)$ & $0(0)$ & $0(0)$ \\
\hline & & 40 & $0(0)$ & $0(0)$ & $0(0)$ & $0(0)$ & $0(0)$ & $0(0)$ & $100(1)$ \\
\hline & & 2 & $50(12)$ & $16(4)$ & $13(3)$ & $0(0)$ & $21(5)$ & $0(0)$ & $0(0)$ \\
\hline & \multirow[t]{2}{*}{ March 2012} & 20 & $17(1)$ & $0(0)$ & $0(0)$ & $0(0)$ & $83(5)$ & $0(0)$ & $0(0)$ \\
\hline & & 40 & $0(0)$ & $0(0)$ & $0(0)$ & $0(0)$ & $100(1)$ & $0(0)$ & $0(0)$ \\
\hline & \multirow{4}{*}{ April 2013} & 2 & $66(49)$ & $34(26)$ & $0(0)$ & $0(0)$ & $0(0)$ & $0(0)$ & $0(0)$ \\
\hline & & 18 & $6(2)$ & $6(2)$ & $9(3)$ & $0(0)$ & $79(25)$ & $0(0)$ & $0(0)$ \\
\hline & & 38 & $0(0)$ & $6(1)$ & $19(3)$ & $0(0)$ & $75(12)$ & $0(0)$ & $0(0)$ \\
\hline & & 2 & $44(4)$ & $44(4)$ & $12(1)$ & $0(0)$ & $0(0)$ & $0(0)$ & $0(0)$ \\
\hline & \multirow{4}{*}{ March 2014} & 10 & $0(0)$ & $13(2)$ & $19(3)$ & $0(0)$ & $68(11)$ & $0(0)$ & $0(0)$ \\
\hline & & 30 & $0(0)$ & $0(0)$ & $10(1)$ & $0(0)$ & $90(9)$ & $0(0)$ & $0(0)$ \\
\hline & & 40 & $0(0)$ & $0(0)$ & $0(0)$ & $0(0)$ & $0(0)$ & $0(0)$ & $0(0)$ \\
\hline & & 50 & $0(0)$ & $0(0)$ & $0(0)$ & $0(0)$ & $100(1)$ & $0(0)$ & $0(0)$ \\
\hline \multirow{11}{*}{$\mathrm{CF}$} & \multirow{3}{*}{ March 2012} & 2 & $50(2)$ & $0(0)$ & $50(2)$ & $0(0)$ & $0(0)$ & $0(0)$ & $0(0)$ \\
\hline & & 20 & $0(0)$ & $0(0)$ & $20(2)$ & $0(0)$ & $80(8)$ & $0(0)$ & $0(0)$ \\
\hline & & 40 & $0(0)$ & $0(0)$ & $0(0)$ & $0(0)$ & $0(0)$ & $0(0)$ & $0(0)$ \\
\hline & \multirow{4}{*}{ April 2013} & 2 & $6(1)$ & $11(2)$ & $17(3)$ & $0(0)$ & $0(0)$ & $66(12)$ & $0(0)$ \\
\hline & & 16.5 & $0(0)$ & $17(1)$ & $66(4)$ & $0(0)$ & $17(1)$ & $0(0)$ & $0(0)$ \\
\hline & & 36.5 & $0(0)$ & $0(0)$ & $7(1)$ & $7(1)$ & $86(12)$ & $0(0)$ & $0(0)$ \\
\hline & & 2 & $0(0)$ & $0(0)$ & $100(1)$ & $0(0)$ & $0(0)$ & $0(0)$ & $0(0)$ \\
\hline & \multirow{4}{*}{ March 2014} & 10 & $0(0)$ & $0(0)$ & $8(1)$ & $0(0)$ & $92(12)$ & $0(0)$ & $0(0)$ \\
\hline & & 30 & $0(0)$ & $0(0)$ & $0(0)$ & $0(0)$ & $100(9)$ & $0(0)$ & $0(0)$ \\
\hline & & 40 & $0(0)$ & $0(0)$ & $0(0)$ & $0(0)$ & $100(1)$ & $0(0)$ & $0(0)$ \\
\hline & & 50 & $0(0)$ & $0(0)$ & $0(0)$ & $0(0)$ & $0(0)$ & $0(0)$ & $0(0)$ \\
\hline \multicolumn{3}{|c|}{ Mean length (cm, range) } & $\begin{array}{c}35.13 \\
(126-578)\end{array}$ & $\begin{array}{c}36.35 \\
(129-448)\end{array}$ & $\begin{array}{c}41.18 \\
(21-679)\end{array}$ & $\begin{array}{r}36.67 \\
(326-39\end{array}$ & $\begin{array}{c}29.61 \\
(102-495)\end{array}$ & 28.47 & 21 \\
\hline \multicolumn{3}{|c|}{ Number of guts with content } & 63 & 57 & 22 & 2 & 117 & 10 & 0 \\
\hline
\end{tabular}


D.N. Nabaes Jodar et al.: Knowl. Manag. Aquat. Ecosyst. 2017, 418, 33

Appendix 3. (A) Standardized coefficients of canonical discriminant functions 1-4. Numbers in bold indicate the largest absolute correlation between each food category and the discriminant functions. (B) Between-species ANOVA on Ranks (Kruskal-Wallis) for each of the four discriminant functions at $2 \mathrm{~m}$ depth. Equal letters indicate lack of significant differences (Dunn's method, $p<0.05$ ).

\begin{tabular}{|c|c|c|c|c|}
\hline & \multicolumn{4}{|c|}{ Function } \\
\hline & 1 & 2 & 3 & 4 \\
\hline \multicolumn{5}{|l|}{ (A) Food category } \\
\hline Aquatic insects & 0.74 & -0.06 & 0.07 & 0.37 \\
\hline Galaxias maculatus & 0.54 & 0.39 & 0.10 & 0.20 \\
\hline Terrestrial insects & -0.44 & -0.05 & -0.10 & -0.29 \\
\hline Decapods & 0.39 & -0.04 & 0.03 & 0.10 \\
\hline Big fish & 0.07 & 0.66 & 0.07 & -0.07 \\
\hline Rodents & 0.07 & 0.61 & 0.07 & -0.08 \\
\hline Pumice stones & 0.01 & 0.44 & -0.14 & 0.22 \\
\hline Snails & -0.34 & 0.06 & 0.86 & 0.33 \\
\hline Synthetic fragments & -0.31 & 0.03 & -0.29 & 0.68 \\
\hline Plant fragments & -0.27 & 0.22 & -0.23 & 0.45 \\
\hline Variance $(\%)$ & 59.26 & 19.47 & 14.12 & 6.53 \\
\hline Accumulated variance $(\%)$ & 59.26 & 78.73 & 92.85 & 99.38 \\
\hline Wilk's lambda & 0.25 & 0.52 & 0.70 & 0.88 \\
\hline Canonical correlation & 0.72 & 0.51 & 0.45 & 0.32 \\
\hline \multicolumn{5}{|l|}{ (B) ANOVA on ranks } \\
\hline O. hatcheri & $\mathrm{a}$ & $\mathrm{ab}$ & $\mathrm{a}$ & $\mathrm{ab}$ \\
\hline P. trucha & $\mathrm{bc}$ & $\mathrm{c}$ & $\mathrm{ad}$ & $\mathrm{a}$ \\
\hline WRT & $\mathrm{ac}$ & $\mathrm{a}$ & $\mathrm{cd}$ & $\mathrm{b}$ \\
\hline ERT & $\mathrm{a}$ & $\mathrm{ab}$ & $\mathrm{bc}$ & $\mathrm{ab}$ \\
\hline Brown trout & $\mathrm{c}$ & $\mathrm{b}$ & $a b c$ & $\mathrm{ab}$ \\
\hline
\end{tabular}

